\title{
Hyperosmia, ectrodactyly, mild intellectual disability, and other defects in a male patient with an X-linked partial microduplication and overexpression of the $K A L 1$ gene
}

\author{
Anna Sowińska-Seidler • Monika Piwecka • \\ Ewelina Olech • Magdalena Socha • \\ Anna Latos-Bieleńska • Aleksander Jamsheer
}

Received: 2 August 2014 /Revised: 7 October 2014 / Accepted: 8 October 2014 / Published online: 23 October 2014

(C) The Author(s) 2014. This article is published with open access at Springerlink.com

\begin{abstract}
Loss-of-function mutations of the $K A L 1$ gene are a known cause of Kallmann syndrome, a disorder characterized by the coexistence of hypogonadotropic hypogonadism and anosmia/hiposmia. On the other hand, neither complete nor partial duplications of $K A L 1$ have been reported in the literature; thus, clinical symptoms associated with such alterations remain unknown. Ectrodactyly is a clinically and genetically heterogeneous abnormality presenting with hypoplasia of the central rays of the extremity, which, in around $68 \%$ of cases, has unknown underlying molecular defect. In this paper, we report on a sporadic male patient manifesting hyperosmia and ectrodactyly accompanied by additional symptoms involving mild intellectual disability, unilateral hearing loss, genital anomalies, stocky build, and facial dysmorphism. Using a combination of high-resolution array comparative genomic
\end{abstract}

A. Sowińska-Seidler $\cdot$ E. Olech $\cdot$ M. Socha $\cdot$ A. Latos-Bieleńska

A. Jamsheer $(\bowtie)$

Department of Medical Genetics, Poznan University of Medical

Sciences, Rokietnicka 8 Street, 60-806 Poznan, Poland

e-mail: jamsheer@wp.pl

A. Sowińska-Seidler

e-mail: asowinskaseidler@gmail.com

E. Olech

e-mail: ewe.olech@gmail.com

M. Socha

e-mail: kozlowicz.m@gmail.com

A. Latos-Bieleńska

e-mail: anna.latosbielenska@gmail.com

M. Piwecka

Institute of Bioorganic Chemistry, Polish Academy of Sciences,

Noskowskiego 12/14 Street, 61-704 Poznan, Poland

e-mail: monikan@ibch.poznan.pl

A. Latos-Bieleńska $\cdot$ A. Jamsheer

NZOZ Center for Medical Genetics GENESIS, 4 Grudzieniec Street,

60-601 Poznan, Poland hybridization (array CGH) and breakpoint analysis, we detected a hemizygous tandem duplication of $110,967 \mathrm{bp}$ on $\mathrm{Xp} 22.31$, encompassing the promoter region and the first two exons of $K A L 1$. In order to confirm pathogenicity of the duplication, we tested the level of KAL1 transcript in blood lymphocytes, showing 79 times higher expression in the proband compared to controls. We, therefore, hypothesize that olfactory hypersensitivity in our proband directly results from $K A L 1$ overproduction. Additionally, a literature review allowed us to conclude that KAL1 protein at high levels may interfere with FGFR1 signaling activity, most probably indirectly giving rise to ectrodactyly, intellectual disability, and genital anomalies. Noteworthy, those symptoms overlap with Hartsfield syndrome caused by FGFR1 loss-of-function mutations. To conclude, our paper highlights the role of KAL1 in embryogenesis and provides data on the contribution of KAL1 overexpression to human pathology.

Keywords $K A L 1$ - Duplication · Anosmin-1 $\cdot$ Hyperosmia . SHFM $\cdot$ Ectrodactyly

\section{Introduction}

Congenital limb anomalies categorized as split hand/foot malformation (SHFM; OMIM 183600) are phenotypically heterogeneous disorders; however, the common characteristic feature shared by all types of SHFM involves the absence or hypoplasia of the central ray(s) of the autopod. In its most severe form, the aplasia of both central and preaxial rays of the hands and/or feet leads to monodactyly. Clinical heterogeneity of SHFM (also referred to as ectrodactyly) results mostly from variable expressivity of the feature, which often manifests inconstantly in closely related patients or even in different limbs of a single individual (Basel et al. 2006). Ectrodactyly 
occurs either as an isolated trait or part of a multiple congenital anomaly syndrome. The malformation is caused by a failure in the development or maintenance of the median apical ectodermal ridge (AER), a group of cells located in the most distal portion of the developing limb bud (Duijf et al. 2003). To date, seven loci associated with non-syndromic SHFM have been described. These include: SHFM1 (OMIM 183600, caused by various rearrangements in the $7 \mathrm{q} 21.3$ locus or point mutations in DLX5), SHFM2 (OMIM 313350, located in Xq26), SHFM3 (OMIM 246500, resulting from tandem duplications of the 10q24-q25 locus), SHFM4 (OMIM 605289, caused by heterozygous mutations in TP63), SHFM5 (OMIM 606708, linked to deletions in the 2q31 locus), SHFM6 (OMIM 22530, associated with homozygous mutations in $W N T 10 B$ ), as well as the most common form, i.e., SHFM/SHFLD3; MIM 612576 (caused by $17 \mathrm{p} 13.3$ duplication encompassing BHLHA9) (Scherer et al. 1994; Faiyaz-Ul-Haque et al. 2005; Gurrieri et al. 1996; van Bokhoven et al. 2001; Klopocki et al. 2012; Goodman et al. 2002; Sowińska-Seidler et al. 2014). Despite recent progress and dissemination of molecular diagnostic and research techniques, the genetic cause of the majority of SHFM cases remains unresolved (Klopocki and Mundlos 2011; Klopocki et al. 2012; Biegański et al. 2012; Tayebi et al. 2014).

Structural copy number variations (CNVs) are a known cause of human limb malformations, and the number of studies associating various $\mathrm{CNVs}$ with developmental limb disorders is constantly growing (Klopocki and Mundlos 2011; Klopocki et al. 2012; Jamsheer et al. 2013). The contribution of submicroscopic genomic rearrangements to the pathogenesis of human malformations can occur via several mechanisms. The most common involves alteration of the copy number of a dosage-sensitive gene or gene cluster. In this setting, deletions or duplications simply lead to the haploinsufficiency or overexpression of a gene, respectively. In some cases, deletions and duplications of the same dosagesusceptible gene give rise to different clinical conditions, as previously shown, for example, for $S O X 9, M E C P 2$, or PMP22 (Benko et al. 2009; Kurth et al. 2009; Meins et al. 2005; Van Esch et al. 2005; Patel et al. 1992; Valentijn et al. 1995; Chance et al. 1993). Alternatively, CNVs can also cause position effects and disturb gene expression by changing the number or location of regulatory elements or by altering the entire regulatory landscape of a target gene or gene cluster (Klopocki and Mundlos 2011).

The KAL1 gene is involved in embryonic development of the kidney and human central nervous system, including the spinal cord, olfactory bulbs, olfactory nerves, and retina (Duke et al. 1995). While KAL1 loss-of-function alterations (i.e., deletions and point mutations) are a known cause of Xlinked Kallmann syndrome (KS), which is characterized by the association of hypogonadotropic hypogonadism $(\mathrm{HH})$ and anosmia/hiposmia, complete or partial duplications of this gene have not been reported in the literature. Thus, clinical symptoms associated with KAL1 duplications and/or increased gene expression remain unknown.

In this paper, we report on a sporadic male patient presenting with SHFM and hyperosmia accompanied with additional congenital abnormalities, most likely resulting from a partial duplication of KAL1 and significant overexpression of this gene. Our paper provides further evidence on the contribution of CNVs to congenital malformations in humans and highlights the role of KAL1 in embryonic development.

\section{Methods}

All patients agreed to participate in this study and informed consent was obtained from all subjects or their legal guardians prior to genetic testing. Ethics approval was granted by the Institutional Review Board of the Poznan University of Medical Sciences.

Array comparative genomic hybridization (array CGH)

Genomic DNA was extracted from peripheral blood leukocytes according to the salting-out method. Array comparative genomic hybridization (array CGH) was carried out with the use of the 1.4M NimbleGen oligonucleotide CGH array (Roche NimbleGen), according to standard protocols provided by the manufacturer. Analysis was done with Deva software (Roche NimbleGen). The analysis settings were as follows: aberration algorithm: ADM-2; threshold: 6.0; window size: $0.2 \mathrm{Mb}$; filter: five probes, $\log _{2}$ ratio $=0.29$. The genomic profile was visualized by the SignalMap Software (SignalMap, NimbleGen Systems, Inc.).

\section{Quantitative real-time polymerase chain reaction (qPCR)}

In order to confirm array CGH results and narrow down the genomic coordinates of the rearrangement, we performed a quantitative real-time polymerase chain reaction (qPCR) using a ViiA ${ }^{\mathrm{TM}} 7$ Real-Time thermal cycler (Applied Biosystems). The qPCR assay was designed to determine the number of copies in the vicinity of both $5^{\prime}$ and $3^{\prime}$ ends of the duplicated Xp22.31 segment. The test was carried out with a set of six and three primer pairs, respectively. The qPCR reaction was performed in a total volume of $12 \mu \mathrm{l}$ in each well containing $6 \mu \mathrm{l}$ of SYBR Green PCR Master Mix (Applied Biosystems), $5 \mu \mathrm{l}$ of genomic DNA ( $2 \mathrm{ng} / \mu \mathrm{l})$, and $0.5 \mu \mathrm{l}$ of forward and reverse primer each $(10 \mu \mathrm{mol} / \mathrm{l})$. The PCR conditions were as follows: initial denaturation step at $95{ }^{\circ} \mathrm{C}$ followed by 40 cycles of denaturation at $95{ }^{\circ} \mathrm{C}$ for $15 \mathrm{~s}$ and annealing with elongation at $60^{\circ} \mathrm{C}$ for $1 \mathrm{~min}$ ). All reactions were run in triplicate. Target sequences were normalized to albumin (ALB) and, to further assure reliability of the assay, 
sex determination was performed in reference to factor VIII (F8) located on the $\mathrm{X}$ chromosome. The gene copy number was determined with the comparative DDCt method using normal healthy control DNA as a calibrator.

\section{Breakpoint sequencing}

The exact breakpoints of the rearrangement were determined with the use of PCR with primers designed to amplify the DNA fragment spanning the $3^{\prime}$ and $5^{\prime}$ ends of the duplication. PCR was performed in a total volume of $10 \mu \mathrm{l}$ containing $1 \mu \mathrm{l}$ of Buffer I (PCR Expand Long Template PCR System v.24; Roche), $0.6 \mu \mathrm{l}$ of primers ( $10 \mu \mathrm{mol} / \mathrm{l}$ each), $0.35 \mu \mathrm{l}$ of dNTPs $\operatorname{mix}(10 \mathrm{mM}), 1 \mu \mathrm{l}$ of genomic DNA $(150 \mathrm{ng} / \mu \mathrm{l}), 0.15 \mu \mathrm{l}$ of DNA polymerase (PCR Expand Long Template PCR System v.24; Roche), and $6.4 \mu \mathrm{l}$ of PCR-grade water. The PCR conditions were as follows: initial denaturation step at $94{ }^{\circ} \mathrm{C}$ for $2 \mathrm{~min}$ followed by 10 cycles of denaturation at $94^{\circ} \mathrm{C}$ for $10 \mathrm{~s}$, annealing at $60^{\circ} \mathrm{C}$ for $30 \mathrm{~s}$, and elongation at $68^{\circ} \mathrm{C}$ for $2 \mathrm{~min}$ ), another 25 cycles of denaturation at $94^{\circ} \mathrm{C}$ for $15 \mathrm{~s}$, annealing at $60^{\circ} \mathrm{C}$ for $30 \mathrm{~s}$, and elongation at $68^{\circ} \mathrm{C}$ for $140 \mathrm{~s}$, and final elongation at $68^{\circ} \mathrm{C}$ for $7 \mathrm{~min}$. The PCR product was then sequenced using dye-terminator chemistry (kit v.3, ABI 3130xl) and run on an automated sequencer, Applied Biosystems PRISM 3700 DNA Analyzer.

\section{$\boldsymbol{K} \boldsymbol{A L} \mathbf{1}$ relative expression}

In order to measure the expression level of the KAL1 gene in our index case, we performed the relative expression analysis for KAL1 in blood samples of the proband and seven controls. Total RNA was extracted from peripheral blood mononuclear cells (PBMCs) of the proband and control samples according to the method of Chomczyński and Sacchi (1987). PBMCs were separated from whole blood in a density gradient of Ficoll and sodium diatrizoate (Histopaque ${ }^{\circledR}-1077$; Sigma). RNA samples were reversely transcribed into cDNA using a mix of oligo-dT and random primers (QuantiTect Reverse Transcription Kit; Qiagen), according to standard protocols provided by the manufacturer.

Quantifications of target and reference genes in cDNA samples were carried out by fluorometric real-time PCR using a LightCycler 480 instrument (Roche Diagnostic $\mathrm{GmbH}$, Mannheim, Germany), a real-time PCR kit (LightCycler ${ }^{\circledR}$ 480 Probes Master), and Universal Probe Library (UPL) probes. For each individual cDNA sample, $\mathrm{Cp}$ values were determined in triplicate. The assay was performed using a 96well plate setup with a final volume of $10 \mu \mathrm{l} /$ well, consisting of $0.5 \mu \mathrm{M}$ of each gene-specific primer, $0.1 \mu \mathrm{M}$ of the appropriate UPL probe, $5 \mu$ l of LightCycler ${ }^{\circledR} 480$ Probes Master mix, $1 \mu$ of the cDNA template, and PCR-grade water. The PCR protocol consisted of an initial denaturation at $95^{\circ} \mathrm{C}$ for $5 \mathrm{~min}$, followed by 45 cycles of amplification consisting of denaturation at $95^{\circ} \mathrm{C}$ for $10 \mathrm{~s}$, annealing at $55^{\circ} \mathrm{C}$ for $30 \mathrm{~s}$, and elongation at $72{ }^{\circ} \mathrm{C}$ for $10 \mathrm{~s}$.

Relative expression values of $K A L 1$ were obtained using the LightCycler480 Software by determining the ratio between the target and two reference transcripts (ACTB, HPRT). Error bars represent the target/reference error calculated by the LightCycler480 Software in a single experiment performed in triplicate. Relative expression values were normalized to the mean of the controls (K1-K7).

Fusion transcript relative expression

The relative expression value of the KAL1 fusion transcript in the proband was determined using the comparative DDCt method by intra-sample normalization to the endogenous control gene $P B G D$ and inter-sample normalization to the $K A L 1$ wild-type transcript, used here as a calibrator. The experiment was carried out with the use of a ViiA ${ }^{\mathrm{TM}} 7$ RealTime PCR System (Applied Biosystems) and SYBR Green PCR Master Mix (Applied Biosystems). The qPCR reaction was performed using a 96-well plate in a total volume of $12 \mu \mathrm{l}$ in each well containing $6 \mu$ of SYBR Green PCR Master Mix (Applied Biosystems), $1 \mu \mathrm{l}$ of cDNA, $0.5 \mu \mathrm{l}$ of forward and reverse primer each $(10 \mu \mathrm{mol} / \mathrm{l})$, and $4 \mu \mathrm{l}$ of PCR-grade water. The PCR conditions were as follows: initial denaturation step at $95{ }^{\circ} \mathrm{C}$ followed by 40 cycles of denaturation at $95{ }^{\circ} \mathrm{C}$ for $15 \mathrm{~s}$ and annealing with elongation at $64{ }^{\circ} \mathrm{C}$ for $1 \mathrm{~min}$ ). All reactions were run in triplicate. Primers for the target sequence were designed to specifically amplify the fusion transcript and not the wild-type form.

\section{Results}

\section{Clinical report}

The proband, a 12-year-old boy of Polish ethnicity, was born by spontaneous delivery after an uneventful pregnancy (G1P1) at 41 weeks and 3 days of gestation to a nonconsanguineous and healthy 21-year-old mother and a 24year-old father. At birth, his weight was 2,980 g (3rd-10th percentile), length $51 \mathrm{~cm}$ (50th percentile), head circumference $32 \mathrm{~cm}$ (below the $3 \mathrm{rd}$ percentile), and his Apgar score was $5,7,9$, and 10 at $1,3,5$, and $10 \mathrm{~min}$, respectively. Physical examination after birth revealed bilateral malformation of the feet composed of hypoplasia and syndactyly of the postaxial toes, which could have been categorized as ectrodactyly. Additionally, the left hand showed a supernumerary digit, which was fused with the index finger. Transfontanellar ultrasound performed after birth and at day 26 revealed bilateral intraventricular hemorrhage (IVH) of the first degree, whereas abdominal ultrasound was normal. X-ray 
scan showed fused processus spinosus of L4 and L5. Hearing tests done at 9 months of age showed profound left-sided hypoacusis and normal right-sided hearing. Ophthalmologic examination was unremarkable. At the age of 3 years, the patient was operated on the hydrocele of the left testis, as well as cryptorchidism of the right testis. According to anamnesis, motor development was normal, with independent sitting and walking achieved on time (6 and 12 months, respectively). Expressive speech was delayed, with the first several words at 4 years of age. Due to congenital defects and delayed speech at that time, the proband was referred for a conventional chromosomal analysis (performed on peripheral blood lymphocytes with a resolution of 550 bands per haploid genome), which showed normal male karyotype (46, XY). Psychological assessment performed at the age of 8 years according to the WISC-R test showed 59 points in the verbal scale, 82 points in the non-verbal scale, and 67 points in the full scale. In addition, at the same time, the patient was diagnosed with attention deficit hyperactivity disorder (ADHD). Throughout the childhood, the boy manifested increased sensitivity to smell. Upon repeated brain magnetic resonance imaging (MRI) scans, a cyst of septum lucidum $5 \times 26 \mathrm{~mm}$ in size was noted. At the age of 11 years and 6 months, the body measurements were as follows: height $141 \mathrm{~cm}$ (25th percentile), weight $50.0 \mathrm{~kg}$ (75th-90th percentile), and body mass index (BMI) 25.25 (90th-97th percentile). Bone age assessment based on left carpal X-ray was relevant to the metrical age.

The boy was referred to our genetic clinic for diagnosis and first investigated at the age of 12 years. Upon examination, he presented with stocky build, obesity, steatomastia, small penis, and craniofacial dysmorphic features comprising round face, full cheeks, hypotelorism, up-slanted palpebral fissures, and hypoplastic alae nasi (no consent for publication of the full- face photo). His upper limb malformation was bilateral and comprised hypoplastic middle and distal phalanges of fingers 2-5 (as shown in Fig. 1a, b). Lower limb malformation could be categorized as ectrodactyly and was composed of hypoplasia and syndactyly of toes $2-5$, which had rudimentary or absent middle and distal phalanges. In addition, both feet showed severe hypoplasia of one digital ray (Fig. 1c, d). Due to the reported increased sensitivity to smell, we decided to perform objective olfactory analyses. While quantitative olfactory examination was symmetrically normal, the registration of olfactory evoked potentials (OEPs) showed considerable increase of the amplitudes symmetrical on both sides. Upon stimulation with peppermint oil and anise oil, the OEP amplitudes were elevated 20 times for nerve $\mathrm{I}(\mathrm{N} 1=320 \mathrm{~ms})$ and 15 times for nerve V (N5=320 ms), showing extreme olfactory hypersensitivity in comparison with the reference values. Endocrinological tests done at 12 years of age showed normal results of TSH, fT3, fT4, FSH, LH PRL, and ACTH. Night release of growth hormone $(\mathrm{GH})$ was unremarkable. Luteinizing hormone-releasing hormone (LH-RH) stimulation test showed normal levels of FSH, LH, and testosterone. The family tree of the proband is presented in Fig. 1e.

\section{Array CGH}

Array CGH performed in the index and subsequently his mother revealed an interstitial microduplication in the Xp22.31 locus, with a minimal size of 108,316 bp (genomic coordinates $8596840-8705155$ according to HG19; shown in Fig. 2a). The duplication encompassed exclusively the promoter region and the first two exons and introns of the KAL1 gene (for a schematic representation, see Fig. 2b) and was inherited from the clinically unaffected mother.
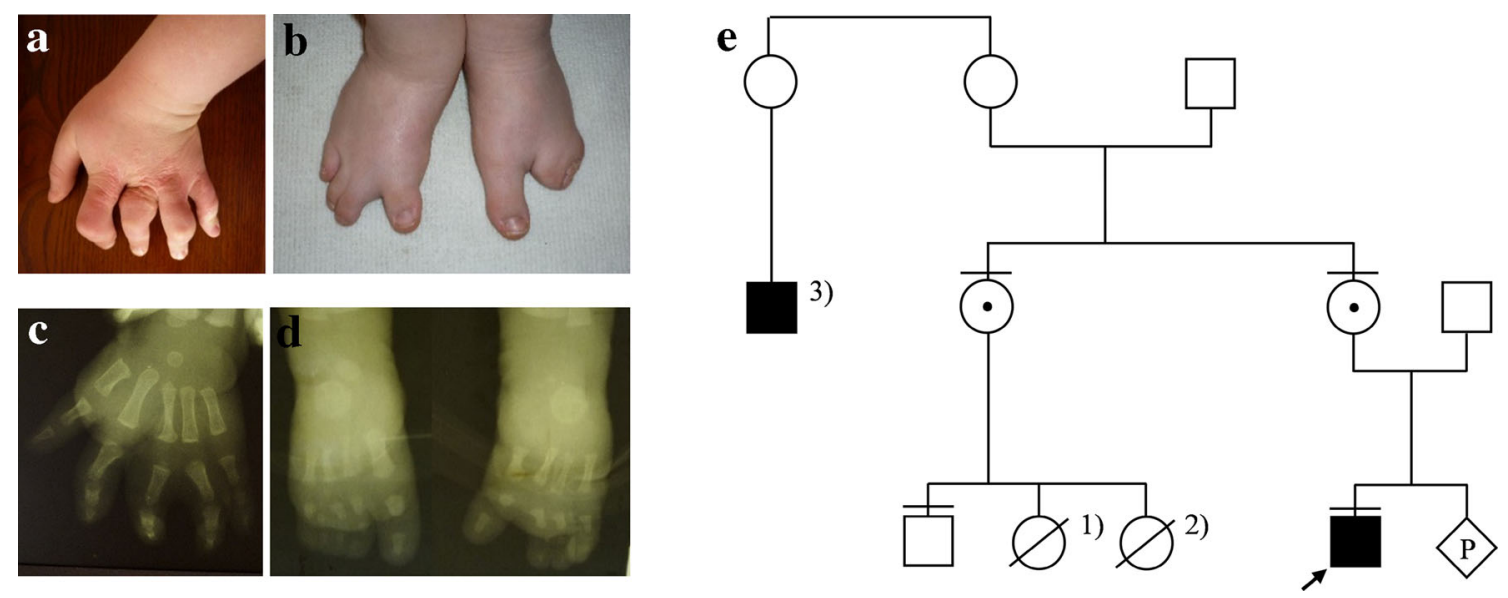

Fig. 1 Limb phenotype of the proband and his family tree: a, b clinical and radiological presentation of the malformation observed in the left hand, $\mathbf{c}, \mathbf{d}$ clinical and radiological picture of the ectrodactyly noted in the proband's feet, e pedigree tree showing that the index case is the only

affected member of the family. The mother of the proband and maternal sister are the healthy carriers of the duplication. Legend for other genetic conditions occurring within this family: 1 gastroschisis, 2 lethal osteogenesis imperfecta, 3 Down syndrome 
$\mathbf{a}$

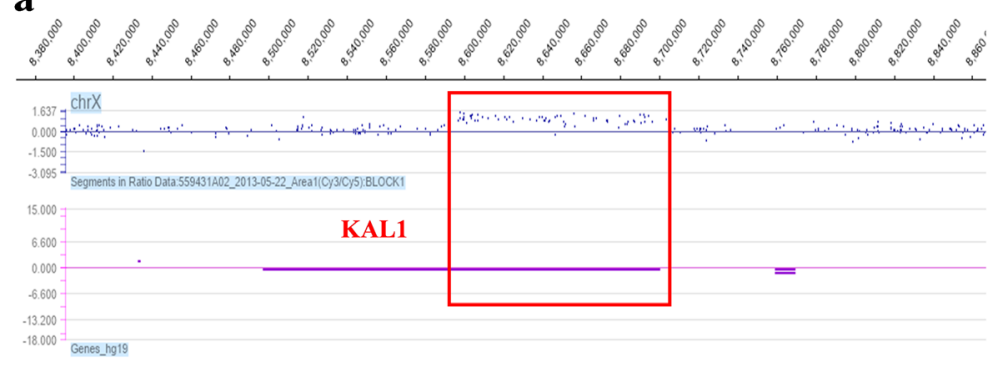

c

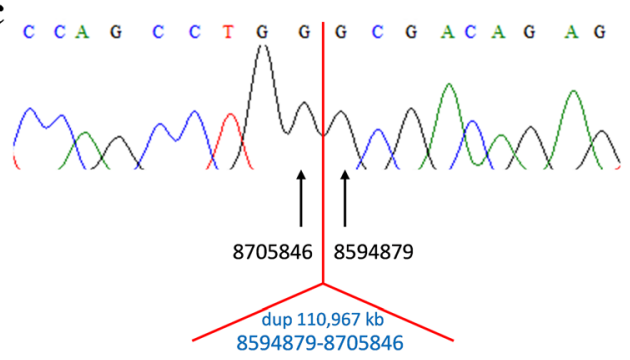

b

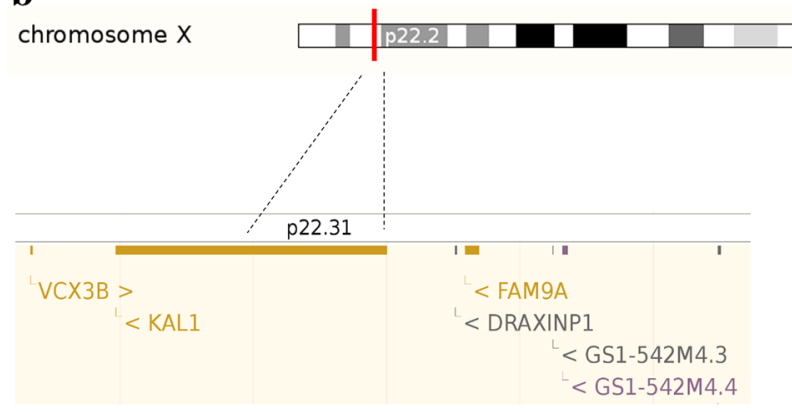

d

MVPGVPGAVLTLCLWLAASSGCLAAGPGAAAARRLDESLSAGSVQRARCASRCLSL QITRISAFFQHFQNNGSLVWCONHKOCSKVVGEEGPAGVEGLNFPAQSRRLPGPQQCS PGAEQGASARARRPRPRPRPAAMVPGVPGAVLTLCLWLAASSGCLAAGPGAAAARR LDESLSAGSVQRARCASRCLSLQITRISAFFOHFONNGSLVWCONHKOCSKCLEPCKE SGDLRKHQCQSFCEPLFPKKSYECLTSCEFLKYILLVKQGDCPAPEKASGFAAACVES CEVDNECSGVKKCCSNGCGHTCQVPKTLYKGVPLKPRKELRFTELQSGQLEVKWSS KFNISIEPVIYVVQRRWNYGIHPSEDDATHWQTVAQTTDERVQLTDIRPSR WYQFRV AAVNVHGTRGFTAPSKHFRSSKDPSAPPAPANLRLANSTVNSDGSVTVTIVWDLPEEP DIPVHHYKVFWSWMVSSKSLVPTKKKRRKTTDGFQNSVILEKLQPDCDYVVELQAIT YWGQTRLKSAKVSLHFTSTHATNNKEQLVKTRKGGIQTQLPFQRRRPTRPLEVGAPF YQDGQLQVKVYWKKTEDPTVNRYHVRWFPEACAHNRTTGSEASSGMTHENYIILQ DLSFSCKYKVTVQPIRPKSHSKAEAVFFTTPPCSALKGKSHKPVGCLGEAGHVLSKVI AKPENLSASFIVQDVNITGHFSWKMAKANLYQPMTGFQVTWAEVTTESRQNSLPNSI ISQSQILPSDHYVLTVPNLRPSTLYRLEVQVLTPGGEGPATIKTFRTPELPPSSAHRSHL KHRHPHHYKPSPERY

Fig. 2 a Ideogram of the array comparative genomic hybridization $(\mathrm{CGH})$ results; the red box indicates the duplicated region encompassing the 5' fragment of the KAL1 gene. b Schematic representation of the microduplication in the Xp22.31 locus. $\mathbf{c}$ Breakpoint sequencing result: a $110,967-\mathrm{kb}$ duplication, with genomic coordinates located between 8594879 and 8705846 according to HG19. d Amino acid sequence of the $K A L 1$ fusion protein; the red box indicates the duplication including the translated fragment of $5^{\prime}$-UTR (marked in red color) and the first two coding exons (highlighted by black and blue colors, respectively). The green color indicates amino acid residues encoded by the exon-exon junctions. (Color figure online)
qPCR and breakpoint analysis

First, the qPCR assay was carried out with a set of five primer pairs in the proband and his mother, in whom it confirmed the array $\mathrm{CGH}$ results. Next, other rounds of qPCR done in the proband allowed to narrow down the duplication region, thereby enabling us to design primers for breakpoint sequencing. The exact breakpoints were established by means of PCR with primers involving centromeric and telomeric ends of the microduplication, followed by Sanger sequencing of the PCR product. The exact size of the duplication was $110,967 \mathrm{bp}$, with genomic coordinates according to HG19 located between 8594879 and 8705846 . The breakpoint spanning sequences are shown in Fig. 2c. Finally, we performed segregation studies in all available family members, i.e., unaffected maternal sister and her healthy son. Using qPCR (five primer pairs), we demonstrated that the maternal sister was a heterozygous carrier of the duplication, whereas her son had a single copy of the tested region.
Fusion transcript analysis

In silico prediction suggested the possibility of the production of two distinct $K A L 1$ transcripts in our proband. In addition to the wild-type transcript, a fusion transcript containing an insert of 405 nucleotides derived from the duplicated KAL1 segment could have been expressed. cDNA sequencing of KAL1 showed the expression of both forms in our proband. The fusion transcript is predicted to give rise to a fusion protein containing 135 additional amino acids at the $5^{\prime}$ end (for the sequence of the putative fusion $K A L 1$ protein, see Fig. 2d).

$\boldsymbol{K} \boldsymbol{A L} 1$ relative expression

The analysis of KAL1 relative expression performed in blood samples of the proband and seven controls revealed 79 times higher expression level of the KAL1 gene in the proband compared to the mean value of the controls (Fig. 3). The 


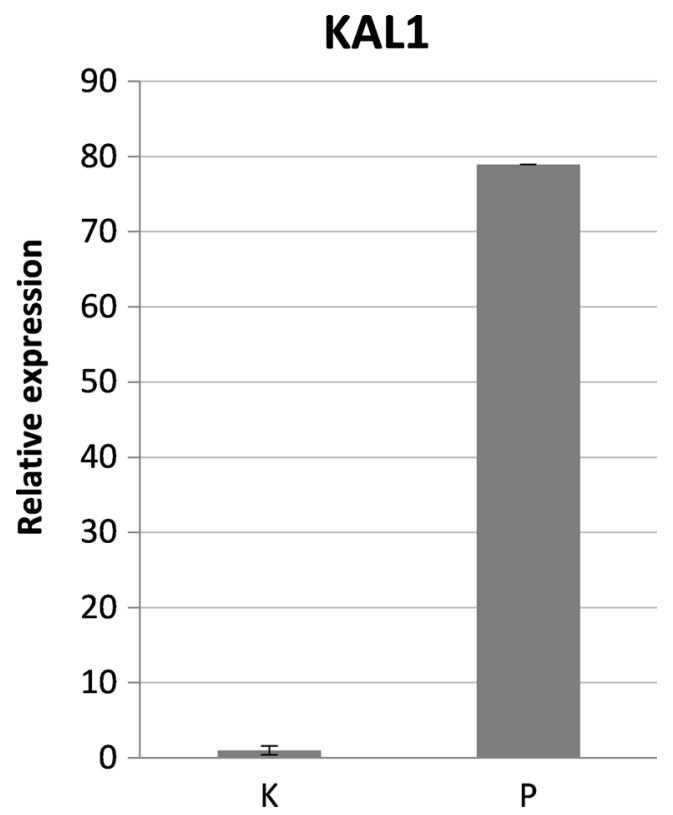

Fig. 3 Bar graph showing the relative expression of $K A L 1$ in the proband in reference to the mean value of seven healthy controls. The expression of the KAL1 transcript in the proband is 79 times higher compared to the controls

relative expression of the fusion $K A L 1$ transcript in our proband referred to the total pool of KAL1 mRNA was $0.3 \%$, suggesting highly preferential expression of the wild-type KAL1 form.

\section{Discussion}

In this paper, we report on a sporadic male patient presenting with SHFM and profound hyperosmia, accompanied with additional symptoms involving mild intellectual disability, unilateral hearing loss, cryptorchidism, small penis, stocky build, and facial dysmorphism. Since the patient did not show any known recognizable genetic syndrome, we performed high-resolution whole-genome array $\mathrm{CGH}$ in order to test for possible imbalanced submicroscopic genomic rearrangement. In the proband, we detected a hemizygous interstitial duplication of $110,967 \mathrm{~kb}$ in the Xp22.31 locus, which encompassed the promoter region and the first two exons of the KAL1 gene. The structural variation showed tandem orientation and was subsequently identified in heterozygosity in the healthy mother of the index case.

The KAL1 gene is expressed during human embryonic development in the spinal cord, kidney, olfactory bulb, and retina (Duke et al. 1995). Its gene product, anosmin-1, represents a secreted extracellular heparin-binding cell adhesion glycoprotein that controls axonal pathfinding and development of olfactory nerves, as well as migration of gonadotropin-releasing hormone $(\mathrm{GnRH})$ producing neurons to the septohypothalamic area (Cariboni et al. 2004). Loss-offunction mutations of $K A L 1$, such as point mutations or deletions of variable size, have been associated with an X-linked form of KS, accounting for 10-12\% of KS cases. The disease is characterized by HH due to GnRH deficiency and anosmia or hiposmia resulting from olfactory bulb dysgenesis. In addition, other anomalies such as sensorineural deafness, renal aplasia, cleft lip/palate, and skeletal defects are known to occur (Dodé et al. 2003). To our knowledge, neither partial nor complete microduplications of KAL1 have been described in the literature. Consequently, the phenotype associated with such CNVs remains unknown. Therefore, since our proband carried a partial duplication of the $5^{\prime}$ end of the $K A L 1$ gene, we tested the expression level of this gene in order to confirm pathogenicity of the CNV. Based on blood lymphocyte studies, our proband showed around 80 times higher expression of the KAL1 gene compared to healthy controls. Unlike KS patients usually affected by hiposmia or anosmia, our proband presented with hyperosmia, which very likely resulted directly from the overproduction of $K A L 1$ during embryonic development. The mechanism by which KAL1 is overexpressed in our proband due to the duplication of its $5^{\prime}$ end remains obscure. One possible explanation is that the duplication encompasses yet unidentified $K A L 1$ enhancer(s), which, by acting in cis in two copies, drive significantly stronger expression of the target gene. Another explanation assumes that, due to the duplication of the promoter region, a putative KAL1 repressor becomes unable to occupy a newly emerging locus, which, in turns, leads to the repressor insufficiency and increase in target gene expression.

The product of $K A L 1$, anosmin-1, is known to directly stimulate tyrosine kinase activity of the fibroblast growth factor receptor 1 (FGFR1), an important signaling molecule involved in a wide range of developmental processes. Loss-offunction mutations of the FGFR1 gene are another cause of KS identified in approximately $10 \%$ of cases (Dodé et al. 2003). The FGFR1-dependent form of KS is inherited in an autosomal dominant manner and frequently presents with limb anomalies such as fusion of the fourth and fifth metacarpals, oligodactyly, and clinodactyly (Jarząbek et al. 2012; Dodé et al. 2003). The role of Fgfrl in embryogenesis was established in mouse developmental studies, in which conditional Fgfrl knockout organisms manifested cerebral and limb anomalies (Tole et al. 2006; Li et al. 2005; Verheyden et al. 2005; Yu and Ornitz 2008). Decreased Fgfrl expression or its complete biallelic inactivation in telencephalon prevents the formation of commissural tracts due to the loss of axonal midline crossing (Tole et al. 2006). In addition, conditional Fgfrl knockout mice show aplasia of digits in the central and anterior rays of the autopods, as well as osseous syndactyly of digits III and IV (Li et al. 2005; Verheyden et al. 2005; Yu and Ornitz 2008). These observations point to the importance of Fgfrl in limb bud and nervous system formation, and explain 
the link between insufficient FGFR1 activity and several human congenital malformations, such as agenesis of corpus callosum, hypoplasia of olfactory bulbs, holoprosencephaly, ectrodactyly, or other limb defects.

It was shown that anosmin-1 stimulates the signaling activity of FGFR1 receptor IIIc isoform via direct binding of its $\mathrm{N}$-terminal region to FGFR1 ectodomains (Hu et al. 2009). On the contrary, at high levels, anosmin-1 can also exert inhibitory effects on the FGFR1 protein ( $\mathrm{Hu}$ et al. 2009; Ornitz 2000). Therefore, in light of these findings, the overexpression of KAL1 might mimic haploinsufficiency of FGFR1 receptor. Interestingly, FGFR1 loss-of-function mutations have been shown to give rise not only to KS but also to several other human genetic conditions, such as isolated $\mathrm{HH}$ or Hartsfield syndrome, a disorder characterized by the co-occurrence of holoprosencephaly and ectrodactyly, in association with developmental delay/intellectual disability, agenesis of corpus callosum, genital anomalies, and variable skeletal malformations (Simonis et al. 2013). Due to significant overlap in the clinical presentation of our proband and Hartsfield syndrome, as well as common biological pathways involved in the development of both conditions, we hypothesize that ectrodactyly, developmental delay, speech delay, intellectual disability, small penis, cryptorchidism, and facial dysmorphism observed in our proband result from the indirect inactivation of FGFR1 due to significant overexpression of $K A L 1$. Of note, there was no evidence for holoprosencephaly upon brain MRI in our patient; therefore, he could not have been diagnosed as having Hartsfield syndrome.

To conclude, in this report, we showed for the first time that increased KAL1 expression may lead to hyperosmia with significantly increased amplitudes of olfactory evoked potentials. Additionally, we postulate that the partial overlap between the phenotype of our patient and Hartsfield syndrome (including ectrodactyly, intellectual disability, and genital anomalies) may reflect the common pathogenic mechanism (i.e., disturbed $F G F R 1$ signaling) underlying both conditions. Finally, we hypothesize that the phenotype of our proband represents a novel, probably rare, $\mathrm{X}$-linked recessive congenital malformation syndrome with ectrodactyly as a limb feature, although further reports are needed in order to confirm our assumptions.

\footnotetext{
Acknowledgments We are grateful to the patients and family members for participating in this study. This work was supported by a grant from the Polish National Science Centre (UMO-2011-03-D-NZ2-06136) to AJ. AS-S was supported by a grant from the Poznan University of Medical Sciences (502-14-01126186-08779), a scholarship support for Ph.D. students from the Polish National Science Centre (UMO-2013/08/ T/NZ2/00027), and a scholarship within the project: "Scholarship support for Ph.D. students specializing in major strategic development for Wielkopolska", Sub-measure 8.2.2 Human Capital Operational Programme, co-financed by the European Union under the European Social Fund.
}

Open Access This article is distributed under the terms of the Creative Commons Attribution License which permits any use, distribution, and reproduction in any medium, provided the original author(s) and the source are credited.

\section{References}

Basel D, Kilpatrick MW, Tsipouras P (2006) The expanding panorama of split hand foot malformation. Am J Med Genet A 140(13):13591365

Benko S, Fantes JA, Amiel J, Kleinjan DJ, Thomas S, Ramsay J, Jamshidi N, Essafi A, Heaney S, Gordon CT, McBride D, Golzio C, Fisher M, Perry P, Abadie V, Ayuso C, Holder-Espinasse M, Kilpatrick N, Lees MM, Picard A, Temple IK, Thomas P, Vazquez MP, Vekemans M, Roest Crollius H, Hastie ND, Munnich A, Etchevers HC, Pelet A, Farlie PG, Fitzpatrick DR, Lyonnet S (2009) Highly conserved non-coding elements on either side of SOX9 associated with Pierre Robin sequence. Nat Genet 41:359364. doi:10.1038/ng.329

Biegański T, Jamsheer A, Sowińska A, Baranska D, Niedzielski K, Kozlowski K, Czarny-Ratajczak M (2012) Three new patients with FATCO: fibular agenesis with ectrodactyly. Am J Med Genet Part A 158A(7):1542-1550. doi:10.1002/ajmg.a.35369

Cariboni A, Pimpinelli F, Colamarino S, Zaninetti R, Piccolella M, Rumio C, Piva F, Rugarli EI, Maggi R (2004) The product of Xlinked Kallmann's syndrome gene (KAL1) affects the migratory activity of gonadotropin-releasing hormone $(\mathrm{GnRH})$-producing neurons. Hum Mol Genet 13(22):2781-2791

Chance PF, Alderson MK, Leppig KA, Lensch MW, Matsunami N, Smith B, Swanson PD, Odelberg SJ, Disteche CM, Bird TD (1993) DNA deletion associated with hereditary neuropathy with liability to pressure palsies. Cell 72(1):143-151

Chomczyński P, Sacchi N (1987) Single-step method of RNA isolation by acid guanidinium thiocyanate-phenol-chloroform extraction. Anal Biochem 162(1):156-159

Dodé C, Levilliers J, Dupont JM, De Paepe A, Le Dû N, SoussiYanicostas N, Coimbra RS, Delmaghani S, Compain-Nouaille S, Baverel F, Pêcheux C, Le Tessier D, Cruaud C, Delpech M, Speleman F, Vermeulen S, Amalfitano A, Bachelot Y, Bouchard P, Cabrol S, Carel JC, Delemarre-van de Waal H, Goulet-Salmon B, Kottler ML, Richard O, Sanchez-Franco F, Saura R, Young J, Petit C, Hardelin JP (2003) Loss-of-function mutations in FGFR1 cause autosomal dominant Kallmann syndrome. Nat Genet 33(4):463-465

Duijf PH, van Bokhoven H, Brunner HG (2003) Pathogenesis of splithand/split-foot malformation. Hum Mol Genet 12(Spec No 1):R51R60

Duke VM, Winyard PJ, Thorogood P, Soothill P, Bouloux PM, Woolf AS (1995) KAL, a gene mutated in Kallmann's syndrome, is expressed in the first trimester of human development. Mol Cell Endocrinol 110(1-2):73-79

Faiyaz-Ul-Haque M, Zaidi SHE, King LM, Haque S, Patel M, Ahmad M, Siddique T, Ahmad W, Tsui LC, Cohn DH (2005) Fine mapping of the X-linked split-hand/split-foot malformation (SHFM2) locus to a $5.1-\mathrm{Mb}$ region on Xq26.3 and analysis of candidate genes. Clin Genet 67:93-97

Goodman FR, Majewski F, Collins AL, Scambler PJ (2002) A 117-kb microdeletion removing HOXD9-HOXD13 and EVX2 causes synpolydactyly. Am J Hum Genet 70:547-555

Gurrieri F, Prinos P, Tackels D, Kilpatrick MW, Allanson J, Genuardi M, Vuckov A, Nanni L, Sangiorgi E, Garofalo G, Nunes ME, Neri G, Schwartz C, Tsipouras P (1996) A split hand-split foot (SHFM3) gene is located at $10 \mathrm{q} 24 \longrightarrow 25$. Am J Med Genet 62:427-436 
Hu Y, Guimond SE, Travers P, Cadman S, Hohenester E, Turnbull JE, Kim SH, Bouloux PM (2009) Novel mechanisms of fibroblast growth factor receptor 1 regulation by extracellular matrix protein anosmin-1. J Biol Chem 284(43):29905-29920. doi:10.1074/jbc. M109.049155

Jamsheer A, Sowińska A, Simon D, Jamsheer-Bratkowska M, Trzeciak T, Latos-Bieleńska A (2013) Bilateral radial agenesis with absent thumbs, complex heart defect, short stature, and facial dysmorphism in a patient with pure distal microduplication of 5q35.2-5q35.3. BMC Med Genet 14:13

Jarząbek K, Wołczyński S, Lesniewicz R, Plessis G, Kottler ML (2012) Evidence that FGFR1 loss-of-function mutations may cause variable skeletal malformations in patients with Kallmann syndrome. Adv Med Sci 57(2):314-321. doi:10.2478/v10039-012-0036-4

Klopocki E, Mundlos S (2011) Copy-number variations, noncoding sequences, and human phenotypes. Annu Rev Genomics Hum Genet 12:53-72. doi:10.1146/annurev-genom-082410-101404

Klopocki E, Lohan S, Doelken SC, Stricker S, Ockeloen CW, Soares Thiele de Aguiar R, Lezirovitz K, Mingroni Netto RC, Jamsheer A, Shah H, Kurth I, Habenicht R, Warman M, Devriendt K, Kordass U, Hempel M, Rajab A, Mäkitie O, Naveed M, Radhakrishna U, Antonarakis SE, Horn D, Mundlos S (2012) Duplications of BHLHA9 are associated with ectrodactyly and tibia hemimelia inherited in non-Mendelian fashion. J Med Genet 49(2):119-125. doi:10.1136/jmedgenet-2011-100409

Kurth I, Klopocki E, Stricker S, van Oosterwijk J, Vanek S, Altmann J, Santos HG, van Harssel JJ, de Ravel T, Wilkie AO, Gal A, Mundlos S (2009) Duplications of noncoding elements $5^{\prime}$ of SOX9 are associated with brachydactylyanonychia. Nat Genet 41(8):862-863. doi:10.1038/ng0809862

Li C, Xu X, Nelson DK, Williams T, Kuehn MR, Deng CX (2005) FGFR1 function at the earliest stages of mouse limb development plays an indispensable role in subsequent autopod morphogenesis. Development 132(21):4755-4764

Meins M, Lehmann J, Gerresheim F, Herchenbach J, Hagedorn M, Hameister K, Epplen JT (2005) Submicroscopic duplication in $\mathrm{Xq} 28$ causes increased expression of the MECP2 gene in a boy with severe mental retardation and features of Rett syndrome. J Med Genet 42(2):e12

Ornitz DM (2000) FGFs, heparan sulfate and FGFRs: complex interactions essential for development. Bioessays 22(2):108-112

Patel PI, Roa BB, Welcher AA, Schoener-Scott R, Trask BJ, Pentao L, Snipes GJ, Garcia CA, Francke U, Shooter EM, Lupski JR, Suter U (1992) The gene for the peripheral myelin protein PMP-22 is a candidate for Charcot-Marie-Tooth disease type 1A. Nat Genet 1(3):159-165
Scherer SW, Poorkaj P, Allen T, Kim J, Geshuri D, Nunes M, Soder S, Stephens K, Pagon RA, Patton MA, Berg MA, Donlon T, Rivera H, Pfeiffer RA, Naritomi K, Hughes H, Genuardi M, Gurrieri F, Neri G, Lovrein E, Magenis E, Tsui LC, Evans JP (1994) Fine mapping of the autosomal dominant split hand/split foot locus on chromosome 7, band q21.3-q22.1. Am J Hum Genet 55(1):12-20

Simonis N, Migeotte I, Lambert N, Perazzolo C, de Silva DC, Dimitrov B, Heinrichs C, Janssens S, Kerr B, Mortier G, Van Vliet G, Lepage P, Casimir G, Abramowicz M, Smits G, Vilain C (2013) FGFR1 mutations cause Hartsfield syndrome, the unique association of holoprosencephaly and ectrodactyly. J Med Genet 50(9):585-592. doi:10.1136/jmedgenet-2013-101603

Sowińska-Seidler A, Socha M, Jamsheer A (2014) Split-hand/foot malformation - molecular cause and implications in genetic counseling. J Appl Genet 55(1):105-115. doi:10.1007/s13353-013-0178-5

Tayebi N, Jamsheer A, Flöttmann R, Sowinska-Seidler A, Doelken SC, Oehl-Jaschkowitz B, Hülsemann W, Habenicht R, Klopocki E, Mundlos S, Spielmann M (2014) Deletions of exons with regulatory activity at the DYNC1I1 locus are associated with split-hand/splitfoot malformation: array CGH screening of 134 unrelated families. Orphanet J Rare Dis 9:108

Tole S, Gutin G, Bhatnagar L, Remedios R, Hébert JM (2006) Development of midline cell types and commissural axon tracts requires Fgfr1 in the cerebrum. Dev Biol 289(1):141-151

Valentijn LJ, Ouvrier RA, van den Bosch NHA, Bolhuis PA, Baas F, Nicholson GA (1995) Déjérine-Sottas neuropathy is associated with a de novo PMP22 mutation. Hum Mutat 5(1):76-80

van Bokhoven H, Hamel BC, Bamshad M, Sangiorgi E, Gurrieri F, Duijf $\mathrm{PH}$, Vanmolkot KR, van Beusekom E, van Beersum SE, Celli J, Merkx GF, Tenconi R, Fryns JP, Verloes A, Newbury-Ecob RA, Raas-Rotschild A, Majewski F, Beemer FA, Janecke A, Chitayat D, Crisponi G, Kayserili H, Yates JR, Neri G, Brunner HG (2001) p63 Gene mutations in EEC syndrome, limb-mammary syndrome, and isolated split hand-split foot malformation suggest a genotypephenotype correlation. Am J Hum Genet 69:481-492

Van Esch H, Bauters M, Ignatius J, Jansen M, Raynaud M, Hollanders K, Lugtenberg D, Bienvenu T, Jensen LR, Gecz J, Moraine C, Marynen P, Fryns JP, Froyen G (2005) Duplication of the MECP2 region is a frequent cause of severe mental retardation and progressive neurological symptoms in males. Am J Hum Genet 77:442-453

Verheyden JM, Lewandoski M, Deng C, Harfe BD, Sun X (2005) Conditional inactivation of Fgfr1 in mouse defines its role in limb bud establishment, outgrowth and digit patterning. Development 132(19):4235-4245

Yu K, Ornitz DM (2008) FGF signaling regulates mesenchymal differentiation and skeletal patterning along the limb bud proximodistal axis. Development 135(3):483-491 